\title{
ALGUPÄRASTE JA TÕLGITUD EESTIKEELSETE TEKSTIDE ERISTATAVUSEST NING NEILE OMISTATUD OMADUSTEST
}

\author{
Marju Taukar
}

\begin{abstract}
Ülevaade. Tõlkeuurimuses on üheks läbivaks uurimisteemaks selgelt äratuntav tõlgitud keel. Artiklis kirjeldan taju-uuringut, mille eesmärgiks oli kindlaks teha, kas lugeja teeb vahet algupärasel tekstil ja tõlgitud tekstil ning mille alusel ta ühe või teise kasuks otsustab. Vastustest selgus, et 1) algupärased ja tõlgitud tekstid ei olnud selgelt eristatavad, 2) oletataval tõlgitud tekstil arvati olevat keelelisi puudusi ning 3) algupärase teksti sõnavara oli vastajate arvates loovam ja eestipärasem. Uurimuse tulemused näitasid selgelt vajadust jätkata korpusuuringuid algupäraste ja tõlgitud tekstide sõnavaraliste erinevuste kohta.
\end{abstract}

Võtmesõnad: tõlgitud keel, kirjeldav tõlkeuurimus, tõlkeuniversaalid, eesti keel

\section{Tõlgitud keel ja tõlkeuniversaalid}

Tõlkeuurimuses on viimastel aastakümnetel uuritud tõlgitud keelt algupärase keele kontekstis. Sellise lähenemise eelduseks on, et tõlgitud keel võib erineda algupärasest. Lähtutakse arusaamast, et tõlgitud keel ei ole ilmtingimata kõrvalekalle normist, tõlge lihtsalt on kuidagi teistsugune kui algupärane tekst (Baker 1993). On uuritud tõlgete ühisjooni (nt Mauranen 2004); leitud, et tõlgitud keelt sihtkeele kontekstis uurides on oluline teha vahet ebapädevast tõlkimisest tulenevatel vigadel ja algupärasest keelekasutusest erineval keelekasutusel (Tirkkonen-Condit 2002), kuid jääb täpsustamata, milliste kriteeriumide alusel seda vahet teha. Üldjoontes arvatakse tõlketekst olevat konservatiivsem, keelekasutuselt standardsem ja ametlikum, sest tõlkides silutakse mittestandardset kirjapilti ja regionaalset kõnepruuki ning tekst on ühtlasem (Baker 2004: 172).

Tõlketeksti lihtsustamisest ja eksplitseerimisest rääkisid oma uurimuste põhjal 1980. aastatel Ria Vanderauwera ning Shoshana Blum-Kulka ja Edward A. Levenston (Laviosa 2002). Tõlkimisprotsessis toimuva on kokku võtnud Mona 
Baker (1993), esitades hüpoteesi tõlkeuniversaalidest, mille kohaselt leiavad tõlkimisel aset muutused, mis ei sõltu keeltest ega tõlkimise suunast. Nende muutuste tagajärjel on tõlgitud tekstid sama keele algupärastest tekstidest tuntavalt erinevad. Lisaks lihtsustamisele ja eksplitseerimisele nimetas ta võimaliku tõlkeuniversaalina ka normaliseerimist - levinumate sihtkeele konstruktsioonide ülekasutamist. Hilisemastes uurimustes on lisandunud teisigi nähtusi, nt sanitiseerimine, mis on lähteteksti kohandamine sihtkeele lugejale vastuvõetavamaks (Kenny 1998: 1). Sonja Tirkkonen-Condit (2002: 209) esitas unikaalsete üksuste hüpoteesi, mille kohaselt esineb tõlgitud tekstis algupärasega võrreldes vähem selliseid elemente, millel puudub lähtekeelne leksikaalne vaste. Gideon Toury (1995) esitatud kasvava standardiseerimise seadus ja interferentsi seadus on tõenäosuslikud ning võtavad arvesse erinevaid keeleväliseid muutujaid.

Bakeri väljatoodud tõlkeuniversaalidest said alguse paljud uurimused ning teda võib pidada ka korpuspõhise tõlkeuurimuse alusepanijaks. Korpusmeetod võimaldas näha palju enamat kui varasemad meetodid. Seepärast on ka algne uurimuste rohkus ja hilisem kriitika igati arusaadav.

Kuigi uurimusi oli palju, jäid tõlkeuniversaalid ise täpselt määratlemata ning nende piirid ja alaliigid on ähmased. Samuti võeti uutes uurimustes kasutusele uusi termineid, mille puhul ei olnud alati aru saada, kas tegemist oli uue termini või uue mõistega. Ei ole päris selge, mis vahe on lihtsustamisel ja normaliseerimisel või sanitiseerimisel ning millises seoses nad on eksplitseerimise või standardiseerimisega. Nii eksplitseerimine kui lihtsustamine muudavad mõlemad teksti jälgimise lihtsamaks, seega on piir nende vahel üsna ähmane (Pym 2008). Mõistete hägusust tunnistatakse viimase aja uurimustes ikka ja jälle, kuid nende defineerimisele ei ole lähedale jõutud.

Ka Baker (2004: 172) kirjutab tõlkeuniversaalidest ja korpusuurimusest kui meetodist kriitiliselt ja möönab, et senini ei ole osatud päris selgelt välja öelda, millisel moel tõlked algupärasest keelest erinevad, kuid arvab siiski, et erinevused peaksid korpusuurimuse abil esile kerkima.

Toury on juhtinud võimalikest universaalidest, seadustest või normidest rääkides tähelepanu nende määratlematusele ja võimaliku defineerimise üle ka arutlenud, kuid jõudnud samuti vaid probleemi olemasolu teadvustamiseni. Näiteks kui öelda, et “tõlkimisel toimub eksplitseerimine”, jäävad välja juhud, kui eksplitseerimist ei toimu või toimub implitseerimine, ning meie väide on vale, ning kui öelda jällegi, et tõlkes on eksplitseerimine kõrvuti implitseerimisega, siis pole me öelnud midagi uut (Toury 2001: 18). Linn Øveråsi inglise ja norra keele tõlgete uurimusest on näha, et lisaks eksplitseerimisele, mida tema otsis, toimus ka implitseerimine (Øverås 1998). On ilmne, et tõlkeuniversaalid või tõlkes toimuvad muutused tuleks täpsemalt defineerida, sest mainitud universaalid on sõnastatud nii üldiselt, et pole aru saada, kus algab üks ja lõpeb teine, või kas üks on teise alaliik. Juliane House (2008) kritiseerib tõlkeuniversaale üldisemalt. Ta seab kahtluse alla nii nende otsimise vajaduse kui nende õigustamise pelgalt sellega, et korpusmeetod sellist uurimist võimaldab.

Tõlkeuniversaale puudutav kriitika on põhjendatud, kuid et tõlkeuniversaalid on olnud kirjeldava tõlkeuurimuse üks olulisi pidepunkte, ei saa sel alal tehtud uurimustest mööda vaadata. Tõlgete eriline keelekasutus on nähtav ka vaatamata sellele, et universaale sellisel kujul, nagu neist algselt räägiti, ei ole. Tõlke uurimisel 
sihtkeele kontekstis on mõtet, eriti kui antud kultuuris ei ole tõlgitud keelt selliselt uuritud. Kõigis uurimustes ilmneb vähemalt mõni nüanss tõlgete süstemaatilise erinemise kohta algupärastest. Minu uurimuse eesmärgiks on saada esialgne pilt tõlgitud eesti keelest.

\section{Uuringu eesmärk, meetod, materjal}

Tõlgitud teksti ja algupärase teksti eristamist uurides leiab Tirkkonen-Condit (2002), et kõigepealt peaks välja selgitama, kas lugeja teeb vahet tõlkel ja algupärasel tekstil - kas tõlgitud keel on tõepoolest nii selgelt äratuntav. Hiljem on tõlgete äratundmisel põhineva taju-uuringu läbi viinud ka Jarmo Harri Jantunen (2004), kelle tulemused langevad Tirkkonen-Conditiga kokku nii õigete vastuste protsendi kui põhjenduste poolest. Mõneti sarnase uuringu on masintõlke uurimise raames teostanud Marco Baroni ja Silvia Bernardini (2006) itaalia keele kohta. Ühest küljest sarnanevad ka nende tulemused siinse ja varasemate uuringutega vastajad ei suutnud tõlgitud tekstidel ja algupärastel tekstidel selgelt vahet teha. Teisest küljest sai äratundmisega paremini hakkama arvutiprogramm, näidates, et vähemalt itaalia keeles on tõlgitud tekstidel ühiseid jooni, mida inimene ei märka, kuid mida arvuti suudab tuvastada.

Siin kirjeldatud taju-uuringu eesmärgiks oli teada saada, kas tõlgitud teksti ja algupärast teksti on võimalik eristada, s.t kas tõlgitud keel on tõepoolest nii spetsiifiline, et lugeja seda märkab. Samuti huvitasid hinnangud ja arvamused tõlgete keele ja algupärase keele kohta. Uuring on kvalitatiivset laadi.

Uurimus seisnes 27 eestikeelse tekstilõigu määramisel tõlkeks või algupäraseks tekstiks. Tekstidest 12 olid algupärased ja 15 tõlgitud. 11 olid ilukirjandustekstid, 3 juhendid ja 3 ajalehe-/ajakirjaartiklid. Tekstide pikkus oli 150-250 tähemärki. Kõik olid toimetatud tekstid täpselt sellisel kujul, nagu need lugejani jõuavad. Tekstides ei asendatud isiku- ega kohanimesid; tõlkele või algupärasele tekstile viitavaid vihjeid sisaldavad lõigud jäid uurimusest välja. Kuigi võiks arvata, et tekstides leiduvad pärisnimed mõjutavad vastajaid, esines tegelikult näiteks võõrapäraseid nimesid nii algupärastes kui tõlgitud tekstides. Mõne teksti puhul toodigi esile võõrapärased nimed, kuid need ei olnud kunagi ainsaks, mille põhjal otsus langetati. Näiteks nenditi, et nimed on imelikud, kuid tekst arvati olevat igati sujuv ning eestipärane.

Vastajaid oli taju-uuringus 23. Neist 6 olid tõlkijad, 14 toimetaja või tõlkija eriala üliõpilased ning 3 vastajat ei olnud tegevad keelega seotud alal.

Vastajatel paluti märkida kõigepealt iga teksti juurde, kas nende arvates on tegemist tõlkega või algupärase eestikeelse tekstiga, ning lisaks kirjeldada, miks nad nii arvavad, või vähemalt märkida tekstis need kohad, mis nende arvamust ühele või teisele poole kallutasid. Enamasti mingi selgitus ka anti. Kõige vähem lisasid kommentaare vastajad, kes ei olnud tegevad ühelgi keelega seotud alal. Muid märkimisväärseid erinevusi ei olnud. 


\section{Tulemused}

Kui tõlketekste oli katses 56\% ja algupäraseid 44\%, siis tõlkeks märgiti 60,9\% ja algupäraseks 35,8\% ning 2,8\% juhtudel ei osatud kummagi kasuks otsustada. Õigeid vastuseid oli 59,7\%.

Kõige rohkem (õigesti) tõlkeks märgitud teksti puhul oli otsus üksmeelne 95\%, kõige rohkem (samuti õigesti) algupäraseks märgitud teksti puhul nõustus $78 \%$ vastajatest. Joonisel 1 on esitatud vastuste jagunemine tekstiti. Tekstid on reastatud tõlkeks märkimiste arvu järgi ning siingi võib näha, et algupäraseid tekste ja tõlketekste on tõlkeks märgitud üldjoontes sarnaselt, tõlketekste pisut sagedamini.

\subsection{Algupäraseks peetud tekstide puhul väljatoodud jooned}

Tekst arvati olevat algupärane, kui sellel ei täheldatud mingeid puudusi: miski ei häirinud, tekstis puudusid võõrapärasused ja vastuolud. Märgiti veel, et tekst oli sorav, sujuv, ladus või loomulik ning isegi pikad laused olid arusaadavad ja voolasid kenasti.

Sageli öeldi nii lauseehituse kui sõnavara kohta, et see on eestipärane, huvitav või leidlik. Mõni tekst võis olla tõlgitud teksti kohta keelekasutuselt liiga vaba või eriline. Algupärasele tekstile viitavad leidlikud sõnad olid näiteks jõmlik, muserdab, puunott, meikar, johtuv, ajad pada. Algupärastes tekstides ja tõlgetes äramärgitud sõnad on koondatud lisasse 1.

\subsection{Tõlkeks märgitud teksti puhul väljatoodud jooned}

Tõlkeks märgitud tekstide puhul põhjendati valikut sagedamini ja täpsemalt kui algupäraseks märkimisel. Põhjendused puudutasid peamiselt tekstide süntaksit ja leksikat. Allpool on esitatud katseisikute hinnangud, millega põhjendati teksti märkimist tõlkeks; lisatud on hinnangut illustreerinud näited, mille algupära katseisik ei teadnud.

1. Kõige rohkem pöörati tähelepanu sõnajärjele ja lausestusele, mis võis olla vale, kohmakas, konarlik.

(1) Asjaolu, et teda üldse ballile kutsuti, üllatas mõnevõrra. (Friedenthal 2005: 41)

2. Mõnes tekstis hinnati lauseid pikkadeks ja lohisevateks. Lause pikkuse kohta mainiti mitmel korral, et algupärase teksti korral teeks autor mõne pika lause mitmeks lauseks, kuid tõlkes on originaali struktuuri järgimine põhjendatud.

(2) Siis ilmnes kuidagi sujuvalt, et tegelikult oskab meie prantsuse külaline ka päris talutavat inglise keelt, minu kolleegid aga saavad vajaduste piires hakkama vene keelega, eriti üks neist, kellele tõlgineiu oli korraga hakanud pakkuma külalisest suurematki huvi, ehkki tema poolt daamile meie kultuuriareaalile nii tüüpilise nihkega avaldatud tähelepanu ei pälvinud märkimisväärset vastulahkust. (Raud 2004: 111) 
Sandra Brown "Kiindumus"

Riikka Pulkkinen "Piir"

Gaby Hauptmann "Täkud"

Per Petterson "Kui me hobusevargil käisime"

Inverter-split tüüpi õhukonditsioneeri kasutusjuhend

Jeffrey Eugenides "Süütud enesetapud"

Kay Cooper "Jäine hirm"

Gilbert Gallerne "Patsient"

Silke Burmeister "Carla Bruni salapäevik"

Sean B. Carroll "Koletised sügavikust"

Majgull Axelsson "See, kes ma kunagi ei olnud"

Anthony Bourdain "Koka rännakud"

Paula Ritanen-Närhi "Klaasveranda pikendab suve"

Jostein Gaarder "Apelsinitüdruk"

Sian Williams "Õnneseente kodu"

Rein Raud "Hector ja Bernard"

Veebikaardi juhend

Jan Kaus "Tema"

Veiko Belials "Jumalate vandenõu"

Aime Hansen "Jaipur-Delhi-Himaalaja..."

Tiina Tammet "Roheline rõdukapp"

Jaan Tangsoo "Perroon"

Rando Soome "'Grusiinlannad" Saka ja Rtveli..."

Meelis Friedenthal "Kuldne aeg"

Silbeti müüriploki juhend

Herman Sergo "Randröövel"

Elme Väljaste "Päriselu proletariaadi puiesteel"

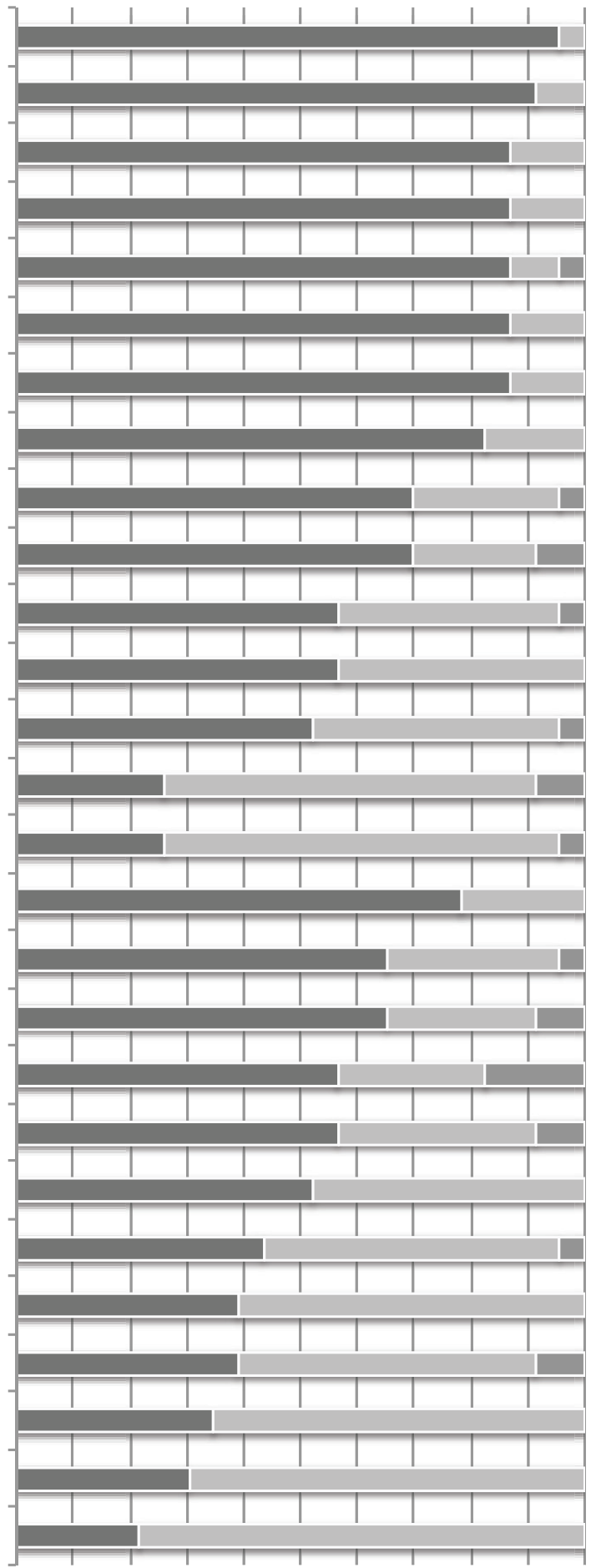

- märgiti tõlkeks घärgiti algupäraseks घ ei osatud otsustada

Joonis 1. Tekstide tõlkeks ja algupäraseks märkimise jaotus 
3. Lauseehituse piires räägiti veel võõrastest, kohmakatest ja lähtekeelele viitavatest konstruktsioonidest.

(3) Nad maiustasid jäätisepallidega, kui Rennie küsis: "Kas teie tunnete hirmuhoogusid?” (Brown 2003: 145)

4. Leiti rektsioonivigu (4) ja ebaühtlust aja- (5) ja isikuvormide (6) kasutamisel.

(4) Mõnikord panevad tugevate ärevushoogude tõttu vaevlevad inimesed sääare kummilindi käe ümber. (Brown 2003: 145)

(5) Ta käed on mu mälus palju selgemad kui tema nägu - nahk oli punane ja küüned kollased. (Axelsson 2006: 44)

(6) Kui nad tunnevad hirmu enda üle võimust võtvat, siis lastakse kumm laksatades lahti. (Brown 2003: 145)

5. Tõlkimise arvele pandi ka mitmesugused kordused: mitmes tekstis leiti olevat liiga palju sidesõnu (7), mõnes asesõnu (8) ja ühes kordus nimisõna tüdruk (9).

(7) Punased ja kollased limonaadikastid ja tormine meri nende taga ja tusane taevas nende kohal. (Kaus 2006: 100)

(8) Keegi ei mõistnud, mis meil sel aastal hakkas või miks me nii meeletult vihkasime surnud putukate koorikuid meie elus. (Eugenides 2005: 52)

(9) Ukse tagant kiirgas eredamat valgust ja tüdruk seisis valgusvihus, uksepiidad raamisid tüdruku piirjooned selgeks ja õhtuks saali paigutatud ringlevad punktvalgustid silitasid tüdruku siluetti kiiresti, kuni pöördusid jälle eemale. See oli just nii, nagu ta oli kujutlenud: tüdrukul olid lumehelbed juustes. (Pulkkinen 2009: 168)

Viimasel juhul on tõepoolest tegemist tõlkega, kuid mitte eesti sooneutraalse asesõna vältimisega, nagu pakuti. Ka soomekeelses originaalis esines sõna tyttö lühikese lõigu jooksul 14 korda. Näite (7) korduste kohta ütles üks vastaja: "häirisid sõnakordused, kuigi hiljem mõeldes tundus loogiline, et sõnakordused esineksid pigem algupärases tekstis." Mõned kordused esinesidki algupärases tekstis, mõned ka tõlkes. Ühe algupärase teksti puhul leiti üksmeelselt, et pidev sidesõna kasutamine lause alguses viitab tõlkele.

6. Sõnavara osas toodi välja üldist võõrapärasust, samuti mõningaid võõrapäraseid väljendeid. Vähemal määral mainiti ära eesti keeles vähem kasutatavaid või konteksti ebasobivaid sõnu; mõnda sõna või väljendit peeti ka otseselt valeks. Kritiseeritud väljendid ja sõnad olid näiteks jõuetu kiskuma puruks, krapsakas valge sein, kas polnud, heilutas, plombiir, oivaliselt. Loend võõrapärasena tundunud sõnadest on lisas 1.

Suurimad erinevused vastajate hinnangutes olidki sõnavara osas. Ühe sõna kohta võidi arvata, et see on tore ja eestipärane, ning järgmises vastuses leiti, et seesama 
sõna on väga imelik või võõrapärane (nt lossida (Sergo 2009: 289), ülemriukameister (Hauptmann 2005: 117)). Kõige enam erinesid sõnavara puudutavad arvamused ainsa varasema (Sergo 2009 [1988]) teksti puhul. Nii toodi ühelt poolt omapäraste ja eestipärastena ning teiselt poolt ebaloomulikuks ja otsetõlkeks peetavatena välja sõnad ja fraasid nagu ilm juba praegu nii külm, et kõorvalestades kinni, jääks tinutada, kuidagi ikka madala pealt lahti tõmbavad, lasti lossida, siis pool tundi aitajat tuult. Arvamused läksid väga selgelt lahku ka kõigi kolme ajakirjandusteksti puhul: vollepiigad, odadeks propaganda malelaulal, mustad nõud ja muu jama, jalamaid, imeõrna varjundiga valge, krapsakas valge sein olid mõne vastaja jaoks eestipärased, mõne jaoks kõlasid eesti algupäraga teksti kohta liiga veidralt.

\section{Tõlgitud keele olemus lugeja arvates}

Siinse uurimuse materjalis ei olnud tõlgitud ja algupärased tekstid vastajate jaoks väga kergesti eristatavad. Uurimuse eesmärgiks oli esiteks teada saada, kas tõlgitud keel on tõepoolest nii spetsiifiline, et lugeja tõlgitud teksti ära tunneb, ning teiseks, mis tekstis tõlgitud keelele viitab. Vastustest nähtus, et 1) selget vahet tõlgitud tekstil ja algupärasel tekstil ei tehtud, 2) oletataval tõlkel arvati midagi viga olevat ja tõlkest räägiti pigem negatiivses toonis ning 3) oletatava algupärase teksti sõnavara arvati olevat eestipärasem ja leidlikum kui tõlgitud teksti sõnavara.

Nii Tirkkonen-Conditi kui Jantuneni tulemused sarnanevad käesoleva tajuuuringu tulemustele. Õigete vastuste protsendid on vastavalt 61,5 (TirkkonenCondit 2002: 210), 62,6 (Jantunen 2004: 561) ning 59,7.

Eestikeelsete tõlgitud tekstide ja algupäraste tekstide määramisel tulid esile vastajate isiklikud eelistused ja negatiivne eelhoiak tõlgitud teksti suhtes. Oletatava tõlketeksti kommenteerimisel kasutati pigem negatiivseid väljendeid, ja sageli väljendati ka isiklikke keelelisi eelistusi. Lisaks tõlkele või algupärasele tekstile viitavatele kommentaaridele tehti teksti kohta parandusettepanekuid, arvati näiteks, et mõni sõna sobiks paremini kui mõni teine. Kui arvutiprogramm on suutnud tõlgitud ja algupärasel tekstil paremini vahet teha kui inimene (Baroni, Bernardini 2006), siis on võimalik, et põhjused peituvad isiklikes eelistustes. Tõlgitud tekstid on ehk küll erinevad, kuid vastajad lähtusid sageli oma eelistustest ning tõlget arvati pigem õigeks peetud normist kõrvalekalduvaks.

Sõnavara osas kerkisid vastustes esile kaks peamist joont. Esiteks kasutatakse vastajate arvates algupärastes tekstides rikkalikumat sõnavara ning teiseks leiti tõlgitud tekstides võõrana mõjuvaid sõnakombinatsioone. Kõige üksmeelsemalt tõlkeks arvatud teksti puhul toodi tõlkele viitavana esile võõrapäraseid või kohmakaid sõnu ning sõnaühendeid, nagu tunnete hirmuhoogusid, kaitseb aju väärsignaali eest, linnast eemal, ratsaklubi lïge, kummilint, maiustasid jäätisepallidega.

Kuigi ei öeldud, et tõlgitud teksti sõnavara on otseselt konservatiivsem, mainiti korduvalt, et oletatava algupärase teksti sõnavara on hea või leidlik või et tõlkija mõne vähem kasutatava või kõnekeelse sõna peale ei tuleks. Teiselt poolt toodi aga oletatava tõlgitud teksti puhul esile võõrapärast sõnavara. Leidlikku ja võõrapärast sõnavara eristada ei olnud võimalik ning piir nende vahel on kas õrn või subjektiivne. Teisalt võib sõnavara leidlikkus või võõrapärasus olla seotud kollokatsioonide või 
korduvate mustritega ning erilised sõnad peavad lugeja jaoks asuma tuttavas mustris, sest eraldiseisvana või vales kohas esinevad erilised sõnad tunduvad kohmakad.

Korduvaid mustreid on tõlgitud ja algupärase keele puhul uuritud mitmetes keeltes ning enamasti on leitud, et need on tõlgitud ja algupärases keeles tõepoolest erinevad (nt Balaskó 2008, Jantunen, Eskola 2002). Neist võib sõltuda, kas keel mõjub loomuliku või võõrana ning leitud on, et kinnistunud konstruktsioonidel, nn poolfabrikaatidel on eriti oluline roll just tehnilises tõlkes (Heltai 2004) ja tehnilises tekstis üldse. Siinse uuringu tulemustest ühtegi otsest kommentaari tehnilise tõlke ja poolfabrikaatide seose kohta ei esinenud, kuid mitmel korral avaldati arvamust, et tehniliste tekstide puhul on keerulisem vahet teha algupärase ja tõlkelise päritoluga tekstidel. Üheks põhjuseks on ilmselt sõnavara, kuid oma roll võib olla rohkel valmis konstruktsioonide kasutamisel.

Seniste tõlgitud ja algupärast keelt võrdlevate uurimuste ja siinse taju-uuringu tulemused erinevad kohati. Vastajad näisid olevat arvamusel, et kui tekstis midagi ei häiri, siis on tegemist algupärase tekstiga. Mainitud varasemate uurimuste põhjal võiks öelda, et kui tõlkimisel toimub normaliseerimine, siis peaks tõlgitud tekst olema sihtkeele vormi sobituv ning konventsionaalne. Seda aga tõlgitud tekstilt ei oodatud. Teisalt, kui tekstis esinev sõnavara oli vastajate arvates leidlik, siis märgiti tekst algupäraseks. Sõnavara lihtsustamisest ja üldistamisest tehtud uurimustes on leitud, et tõlgetes kasutatakse rohkem sagedamini esinevat sõnavara ning selle põhjuseks on eesmärk kirjutada kergesti loetav tekst. Tõlkes toimuvate muutuste põhjuseid ei ole enamasti käsitletud, piirdutud on võimalike muutuste otsimisega ja tõlgitud keele olemuse kirjeldamisega.

\section{Kokkuvõtteks}

Artikkel käsitles tõlgitud keele uurimist algupärase keele kontekstis. Kirjeldavas tõlkeuurimuses on selliste uurimuste lähtekohaks olnud sageli tõlkeuniversaalid, seadused või normid. Teisalt ei ole veel jõutud nende täpse defineerimiseni ning puhuti on kahtluse alla seatud nende olemasolu ja põhjendatus. Siiski tõdetakse ikka ja jälle, et tõlgitud tekst erineb algupärasest tekstist. Siinne uuring kontrollis seda seisukohta eestikeelsete tekstide materjalil. Tõlgete äratundmisel põhineva taju-uuringu tulemusena selgus, et väga selget vahet tõlkel ja algupärasel tekstil ei olnud võimalik teha. Tõlgitud keelt peeti enamasti lugeja poolt õigeks peetavast normist kõrvalekalduvaks. Kui tekstis leidus leidlikku või põnevamat sõnavara, siis arvati tegemist olevat algupärase tekstiga. Algupärastena toodi välja üksikuid sõnu, samas kui tõlketekstist arvati märku andvat pigem ebaõnnestunud, eesti keelele võõrad sõnaühendid.

Varasemate uurimuste ja siinse taju-uuringu tulemuste valguses tuleb selgelt välja vajadus jätkata korpusmeetodil põhineva uurimusega, mis annaks aimu, milline on eestikeelne tõlgitud tekst tegelikult. Taju-uuringu vastuste seast kerkis edasist uurimist vajavana esile seisukoht, et algupärane sõnavara on eestipärane ja leidlik ning tõlketeksti fraasid võõrapärased. 


\section{Materjali allikad}

\section{Tõlgitud tekstid}

Axelsson, Majgull 2006. Need, kes ma kunagi ei olnud. Tõlkinud Raili Väin. Tallinn: Pegasus. Bourdain, Anthony 2003. Koka rännakud. Tõlkinud Juhan Habicht. Tallinn: Varrak. Brown, Sandra 2003. Kiindumus. Tõlkinud Mati Piirimaa. Tallinn: Ersen.

Burmeister, Silke 2009. Carla Bruni salapäevik. Tõlkinud Maris Jakobson. Tallinn: Olion. Carroll, Sean B. 2010. Koletised sügavusest. - Tarkade Klubi, 5 (41). Tallinn: Presshouse. Cooper, Key 2008. Jäine hirm. Tõlkinud Leena Suits. Tallinn: Ersen.

Eugenides, Jeffrey 2005. Süütud enesetapud. Tõlkinud Liia Piirmets. Tallinn: Pegasus. Gaarder, Jostein 2005. Apelsinitüdruk. Tõlkinud Karel Zova. Tallinn: Koolibri. Gallerne, Gilbert 2008. Patsient. Tõlkinud Margot Endjärv. Tallinn: Eesti Raamat. Hauptmann, Gaby 2005. Täkud. Tõlkinud Tiina Aro. Tallinn: Tormikiri.

Inverter-split tüüpi õhukonditsioneeri kasutusjuhend. http://www.bvtpartners.ee/content/ files/AWI O26 35HPDC1 user manual Estonian.pdf (06.02.2011).

Petterson, Per 2010. Kui me hobusevargil käisime. Tõlkinud Kai Mai Aja. Tallinn: Pegasus. Pulkkinen, Riikka 2009. Piir. Tõlkinud Monika Pais. Tallinn: Pegasus.

Ritanen-Närhi, Paula 2009. Klaasveranda pikendab suve. - Tehnikamaailma Kodu ja Ehitus, 8. Tallinn: Ühinenud Ajakirjad AS.

Williams, Sian 2011. Õnneseente kodu. - Kodu ja Aed, dets. Tallinn: OÜ Formamedia.

\section{Algupärased tekstid}

Belials, Veiko 2006. Jumalate vandenõu. Tallinn: Varrak.

Friedenthal, Meelis 2005. Kuldne aeg. Tallinn: Tuum.

Hansen, Aime 2009. Jaipur-Delhi-Himaalaja: reisikohvrist leitud lood. Tallinn: Varrak.

Kaus, Jan 2006. Tema. Tallinn: Tuum.

PRIA veebikaardirakenduse kasutusjuhend. https://kls.eesti.ee/pria avalik kaart/doc/ veebikaardi kasutusjuhend.pdf (06.02.2011).

Raud, Rein 2004. Hector ja Bernard. Tallinn: Tuum.

Sergo, Hermann 2009 [1988]. Randröövel. Tallinn: Pegasus.

Silbeti müüriplokkide kasutusjuhend. http://www.silbet.ee/kasutusjuhend.pdf (06.02.2011). Tammet, Tiina 2010. Roheline rõdukapp. - Kodu ja Aed, okt. Tallinn: OÜ Formamedia.

Soome, Rando 2009. "Grusiinlannad" Saka ja Rtveli, kangelased tiigrinahas. - Sporditäht, 14. jaanuar. Tallinn: Kalev Meedia.

Tangsoo, Jaan 2010. Perroon. Tallinn: Eesti Raamat.

Väljaste, Elme 2007. Päriselu proletariaadi puiesteel. Tallinn: Varrak.

\section{Viidatud kirjandus}

Balaskó, Maria 2008. What does the figure show? Patterns of translationese in a Hungarian comparable corpus. - trans-kom, 1 (1), 58-73.

Baker, Mona 1993. Corpus linguistics and translation studies: Implications and applications. - Mona Baker, Gill Francis, Elena Tognini Bonelli (Eds.). Text and Technology. Amsterdam: John Benjamins, 233-250.

Baker, Mona 2004. A corpus-based view of similarity and difference in translation. - International Journal of Corpus Linguistics, 9 (2), 167-193. http://dx.doi.org/10.1075/ ijcl.9.2.02bak

Baroni, Marco; Bernardini, Silvia 2006. A new approach to the study of translationese: Machine-learning the difference between original and translated text. - Literary and Linguistic Computing, 21 (3), 259-274. http://dx.doi.org/10.1093/llc/fqio39 
Heltai, Pál 2004. Ready-Made language and translation. - Gyde Hansen, Kirsten Malmkjær, Daniel Gile (Eds.). Claims, Changes and Challenges in Translation Studies: Selected Contributions from the EST Congress, Copenhagen 2001. Benjamins Translation Library, 50. Amsterdam, Philadelphia: John Benjamins Publishing Company, 51-71.

House, Juliane 2008. Beyond intervention: Universals in translation. - trans-kom, 1 (1), 6-19. http://www.trans-kom.eu/bdo1nro1/transkom_01_01_02_House_Beyond_Intervention.20080707.pdf (5.05.2011).

Jantunen, Jarmo Harri 2004. Suomennosten kieliasu puntarissa. - Virittäjä, 4, 559-572. http://www.kotikielenseura.fi/virittaja/hakemistot/jutut/2004_559.pdf (5.05.2011).

Jantunen, Jarmo Harri; Eskola, Sari 2002. Käännössuomi kielivarianttina: syntaktisia ja leksikaalisia erityspiirteita. - Virittäjä, 2, 184-207. http://www.kotikielenseura.fi/ virittaja/hakemistot/jutut/2002 184.pdf (24.03.2011).

Kenny, Dorothy 1998. Creatures of habit? What translators usually do with words. - Meta: Journal des Traducteurs / Meta: Translators' Journal, 43 (4), 515-523.

Laviosa, Sara 2002. Corpus-based Translation Studies: Theory, Findings, Applications. Approaches to Translation Studies, 17. Amsterdam: Rodopi.

Mauranen, Anna 2004. Corpora, universals, and interference. - Anna Mauranen, Pekka Kujamäki (Eds.). Translation Universals. Do They Exist? Benjamins Translation Library, 48. Amsterdam, Philadelphia: John Benjamins: 65-82.

Øverås, Linn 1998. In search of the third code. - Meta: Journal des Traducteurs / Meta: Translators' Journal, 43 (4), 557-570. http://id.erudit.org/revue/meta/1998/v43/ n4/003775ar.pdf (27.04.2011).

Pym, Anthony 2008. On Toury's laws of how translators translate. - http://www.scribd. com/doc/3735779/Toury-Laws (5.05.2011).

Tirkkonen-Condit, Sonja 2002. Translationese, a myth or an empirical fact? A study into the linguistic identifiability of translated language. - Target, 14 (2), 207-220. http:// dx.doi.org/10.1075/target.14.2.02tir

Toury, Gideon 1995. Descriptive Translation Studies and Beyond. Amsterdam/Philadelphia: John Benjamins Publishing Company.

Toury, Gideon 2001. Probabilistic explanations in Translation Studies: Universals - or a challenge to the very concept? - Gyde Hansen, Kirsten Malmkjær, Daniel Gile (Eds.). Claims, Changes and Challenges in Translation Studies: Selected Contributions from the EST Congress, Copenhagen 2001. Benjamins Translation Library, 50. Amsterdam, Philadelphia: John Benjamins Publishing Company, 15-25.

Marju Taukar (Tallinna Ülikool), uurimisvaldkonnaks on tõlkimine ja tõlgitud keel. marjutaukar@gmail.com 


\section{Lisa 1.}

\section{Algupäraseks peetud sõnad ja fraasid}

kurk kuivas ropult

johtuv

jõmlik

jäässe tõmmata

kõhedaks

käed-jalad tööd täis

lainelokse

latrajail

meikar

muserdab

nišši

osmiku

piskuks ajaks

sõnavaht

täielik gei

vennaarmust pajatav

ropult

puunott

säherdune

võhma

\section{Tõlkeks peetud sõnad ja fraasid}

andestust?

desserttaldrikutele

haletsusväärne mälukaotanud

heilutas

ei tulegi usaldada

jõuetu kiskuma puruks

kastide armee

keegi kolmas

krapsakas valge sein

kummilint

laev madalal

maiustaksid jäätisepallidega

läheksid kuulajatel toidupalad kurku

plombiir

saab mu kogemus kinnitust

tuleb tagasi nagu kummitus

B. lükkus kaugele ära

oma enamuses mitte

lossida

ratsaklubi 


\title{
ON THE IDENTIFIABILITY AND CHARACTERISTICS OF TRANSLATIONS AND NON-TRANSLATIONS IN ESTONIAN
}

\author{
Marju Taukar \\ Tallinn University
}

The focus of descriptive translation studies has for a few decades been on translated language in the context of non-translated language. The impulse for research has been an attitude that translations in a language differ linguistically from nontranslations in the same language. Even though the difference is usually stressed as not deriving from straightforward mistakes, the common attitude towards translations and also the prevailing view of translations in the study discussed in this article is that there is something wrong with the translation. The aim of the study was to investigate whether readers can distinguish between translations and non-translations in Estonian and what linguistic features are described as creating the impression of a translation or a non-translation. The two broad features that, according to respondents, indicate non-translationality are a flowing, fluent text and creative vocabulary. Features suggesting that a text is a translation are deviations from the linguistic norm (or what the respondent regards as the norm) and unnatural lexical strings. The article places the study in the context where translation universals have been sought for to show what lies behind the impression of strangeness claimed present in translations. This context involves also a discussion of the critique of translation universals.

Keywords: translational language, descriptive translation studies, translation universals, Estonian 